\title{
Challenges and Countermeasures of Ideological and Political Education of College Students under "New Normal"
}

\author{
Dafan Shu \\ College of Information Science and Engineering \\ Wuhan University of Science and Technology \\ Wuhan, Hubei, China 430081
}

\begin{abstract}
Ideological and political education of college students is influenced by "New Normal" such as diversification of social ideological trend, new media application, and integration of ideological and political education system of college students, university education and management reform as well as enhancement of students' independent consciousness. In face of various emerging problems and challenges, it is necessary to energetically strengthen "four in one" construction of ideological guarantee, intellectual support, organization guarantee and motive force supporting of ideological and political education of college students, in order to cultivate college students into qualified builders and successors of socialism.
\end{abstract}

Keywords-new normal; college students; ideological and political education

\section{INTRODUCTION}

New Normal means returning to the normal state after a period of abnormal state. Under the general background of "New Normal" of national economy in our country, ideological and political education of college students also enters "New Normal". Only through adapting to challenges brought by "New Normal" and seizing the opportunity can boost the improvement of ideological and political education of college students and promote the comprehensive development of students.

\section{NEW NORMAL OF IDEOLOGICAL AND POLITICAL EDUCATION OF COLLEGE STUDENTS}

The first is diversification of social ideological trend. Social ideological trend refers to the ideological trend that has some tendentiousness and significance within some range as well as certain corresponding theoretical form and establishes on the basis of certain social mentality under specific social and historical background. Since more than 30 years of reform and opening up, earth-shaking changes have taken up in the society, economy, politics and culture of our country. It brings prosperity as well as new contradictions and requests. These contradictions and requests are different. The comprehensive manifestation of them presenting on social consciousness of people are different, which form different social ideological trends. [1] At present, ten ideological trends in society include neo-liberalism, nationalism, New Left, Populism, universal value, ecologism, Historical Nihilism, extremism, new Confucianism and thoughts of constitutional government. From now on, the diversification of social ideological trends will become a New Normal for a long time.

The second is application of new media. New media is the communication pattern that provides users with information and service through digital, interactive, fixed or mobile multimedia terminal. Compared with four traditional media, the press, outdoors, broadcast and television, network new media is vividly called "the fifth media". [2] New media has characteristics of trans-time-space, real-time interactivity, multimedia feature and openness. It has powerful network system, rich resources, explosive information, fast transmission and interaction and becomes important channel for students to get and exchange information and express ideas. The application of new media becomes New Normal.

The third is university education and management reform. With transformation and upgrading of social economy in our country, in order to meet requirements of national construction in the new period for talents of higher education, university education and management reform carry forward continuously. The reform of credit system and online courses are the most prominent. The credit system changes the original mode of class teaching, breaks through traditional administrative class division and realizes diversification of students' self-education, self-management and self-service carrier. Online courses enrich students' selection and realize sharing of high quality resources.

The fourth is integration of ideological and political education system of college students. Ideological and political education system of college students contains total elements, full coverage and all participants in the whole process of ideological and political education of college students. In this system, the core layer is the work team of ideological and political education of college students, including cadres of party and government, communist youth league cadres, teachers of ideological and political theory course as well as philosophy and social science course, instructors and class teacher in schools. The second layer is various courses in 
universities and all other faulty members. The outermost layer is all organizations and institutions in society. All strengths that help the ideological and political work of college students build layers of firewalls for ideological and political education of college students. In face of fierce competition for college students in the ideological sphere, the coordination and cooperation between different layers and within the same layer are of vital importance.

The fifth is strengthening of students' independent consciousness. The so-called independent consciousness refers to correct evaluation and understanding of people for themselves and the ability to dominate and control their actions. The core is independence, self-confidence and autonomy. Independent consciousness is outstanding feature and key element of modernization of people. [3] Contemporary college students are mainly born after 1995. As the generation born in fast development of social economy, their independent consciousness strengthens obviously. They have active thinking, accept new things with pleasure and do not trust authority blindly, have the courage to challenge and dare to innovate. However, under the influence of complicated society, family environment and personal factors, the independent consciousness of college students shows ego, self-abasement, self-conceit, self-willed feature and psychological inversion and follows blindly. They are the combination of contradictions. But college students' character can be shaped very easily, if the method is proper, they can grow up into talents under positive guidance.

\section{PROBlEMS AND CHALLENGES EXISTING IN IDEOLOGICAL AND POLITICAL EDUCATION OF COLLEGE STUDENTS UNDER NEW NORMAL}

\section{A. Dominant Position of Socialist Core Values Is Challenged}

Socialist core values are the fundamental guarantee to adhere to the road of socialism with Chinese characteristics, carry forward Chinese spirit and adhere to concentrate Chinese strength. [4] As an open organization with the feature of socialization, universities are impacted by various kinds of social ideological trends. College students are very precious talent resources, hope of the nation, and the future of our country. They are in the key period to form world outlook, outlook on life and values. Western hostile forces want to divide and westernize our country all the time. The competition for the next generation of our country will become more violent and complicated. They pay attention to using religion, so-called non-governmental organizations, commonweal organizations and social organizations to penetrate into the group of college students, publicize core values of western capitalism with "freedom, democracy, equality and human rights" as the slogan. It obviously has negative influence on formation of college students' socialist core values. Some college students lack clear political conviction, ideals and faith but have distorted values, which challenge the dominant position of socialist core values.

\section{B. Traditional Ideological and Political Education Forms of College Students Are Impacted}

Compared with traditional closed systems with singledirection dissemination such as television, broadcast and newspaper, new media such as WeChat, microblog, BBS and QQ have open and multidirectional dissemination characteristics. It is difficult to select and control dissemination of information. A large number of unhealthy, unscientific and uncivilized information and some information that slander socialism and advocate western mainstream value have negative effects on college students who are building correct world outlook, outlook on life and values, make them doubt even oppose and attack the education received by them on socialist core values and communism belief. The openness and virtuality of new media are easy to let students realize "deindividualization". If losing individualization, college students will obviously lose consciousness of responsibility and perform some extreme behaviors, such as abuse others and carry out hostile attack on the internet and cannot distinguish realistic society and virtual society. The application of new media impacts the effects of traditional ideological and political education of college students.

With the reform of credit system in universities and online courses, some teachers use single and few methods and their work has no relationship with practice. At present, the ideological and political education of college students pays attention to theory, tradition and offline education but thinks little of practice, innovation and online education. It mainly shows that the contents of theory courses are antiquated. The teaching form is single with poor appeal; the practice courses become formalistic. In terms of the site, activity planning, funds of activity or organization, the enthusiasm of students for participation cannot meet the requirements of linking theory with practice. It cannot enlighten and sublime students' thoughts. Traditional ways lack appeal and vitality and innovation means and cannot realize full coverage. The qualities of offline courses are different. Teaching methods are boring. Students have low degree of participation. The resources of online courses are limited. The coverage is not enough.

\section{Systems of Ideological and Political Education of College Students Work Separately without Enough Cooperation}

Ideological and political education of college students is a systematic engineering. It needs all layers to closely cooperate with each other. At present, the tightness and cooperation between different systems are not enough, which mainly shows between different layers and within the same layer. The core layer has the biggest influence on tightness and cooperation within the same layer. Because units of the core layer have different division of labor in schools, they have different responsibilities, too. For example, cadres of party and government in schools are mainly responsible for design, support and assessment of ideological and political education of college students. Teachers of ideological and political theory course and philosophy and social science course are mainly responsible for teaching of theory courses and practice courses. Instructors and class teachers are responsible for daily ideological and political education of students and daily 
management. It seems that they go forward one by one from top to bottom. In reality, these units often work independently without enough cooperation. Marxism, the theoretical system of socialism with Chinese characteristics and socialist core values learnt by students in class need the demonstration and support of the second layer and the outermost layer. If opinions on public affairs or behaviors of participants from the other two layers go against theory and practice taught by schools, students will be confused by a sentence and a behavior of other organizations or people, even though schools teach things as many as possible to them.

\section{Subjectivity of Students in Ideological and Political Education of College Students Is Not Prominent}

College students are the principal part of ideological and political education. All work related to ideological and political education shall focus on college students. With strengthening of independent consciousness of college students, they begin to doubt and criticize knowledge learnt by them. Traditional way of one-way "Duck-stuffing" type of teaching has become less popular with students. In actual ideological education of college students, the implementers often look down from a height and arrange all links for students from theoretical study to practice, neglect independent consciousness of college students, limit students to use thinking of their own to think social life and value of life. It is difficult for them to meet students' emotional needs to understand themselves, know about the society and discover the world. The subjectivity of college students is not prominent enough. They always get half the result with twice the effort and cannot achieve the desired effects.

\section{IV. "FOUR IN ONE" PROMOTES THE ACHIEVEMENT OF IDEOLOGICAL AND POLITICAL EDUCATION RESULTS OF COLLEGE STUDENTS UNDER NEW NORMAL}

\section{A. Adhere to Take Socialist Core Values as the Guidance and Provide Ideological Guarantee for Ideological and Political Education of College Students}

Socialist core values are the ideology of socialism. It takes Marxism as the guidance and embodies world outlook, the outlook on life and values of Marxism, contains value assessment standards of excellent culture and moral and manners of Chinese nation, [4] and promotes the situation that the ideological and political education of college students under New Normal must adhere to take socialist core values as the guidance, provides ideological guarantee for ideological and political education of college students. Firstly, truly tell Chinese stories with human feelings from emotions and viewpoint of students through picture show, report on people, films and television programs, use these stories to let students feel profound changes brought by times transformation for Chinese society and then establish and firm self-confidence in road, theory and political system. Secondly, carry out various forms of ideal and belief education, patriotism education, citizen moral education and quality-oriented education for college students, let students absorb nutrients from great achievements of Chinese revolution, construction and reform and opening up, development and progress of the times through great practice of socialism, excellent culture and moral and behaviors of Chinese nation, improvement of comprehensive quality of college students, and have more indepth cognition of formation and development of socialist core values. Finally, guide college students to put into social practice, set about from four aspects of "diligent learning, moral cultivation, clear discrimination and honesty and sincerity", set up and cultivate socialist core values.

\section{B. Strengthen Teachers' Ethics and Vocational Ability Construction of Work Team of Ideological and Political Education and Provide Intellectual Support for Ideological and Political Education of College Students}

As organizer and implementer of ideological and political education of college students, ideological and political work team first serves as teachers. The construction of teachers' ethics belongs to high-level spiritual realms such as outlook on life, values, moral cultivation and spiritual outlook and the key to strengthen appeal, persuasion and personality charm of teachers. In construction of strengthening teachers' ethics, firstly, it is necessary for teachers to strengthen learning, renew ideas and set up ideas such as "impart knowledge and educate people", "educate people by management" and "educate people through service", require themselves according to ideas of socialist core values, set examples for students, use development view to look at problems and continuously improve ways and methods of working; secondly, strengthen construction of campus culture, enrich spiritual and cultural life of work team, reinforce formative education of moral education, let teachers feel the difficulty of ideological and political work and sense of achievement and happiness of educating people. Lastly, establish and improve assessment and incentive mechanism and arouse the enthusiasm and initiative of work team.

The vocational ability of ideological and political education work team of college students refers to the integration of abilities required by ideological and political education. The basic knowledge covers basic principles and knowledge of many disciplines such as Marxist theory, philosophy, political science, pedagogy, mental philosophy and the science of law. Professional knowledge covers ideological and political education, Sinicization of Marxism, knowledge related to practical work of ideological and political education of college students, knowledge of laws and regulations. Except for broad scope of knowledge, work skills and practical experience are more important. Firstly, strengthen training, pay attention to theory and practice learning, enrich themselves and make efforts to be perfect at a skill; secondly, strengthen the research on work objects and problems, enhance understanding for their own work, find out rules and internal connection; finally, strengthen practical training and strengthen the ability level of ideological and political team of college students through workshop, teaching contest of ideological and political course, instructors' ability contest, blog article contest and competition of new media application. 


\section{Strengthen Integrated Construction of Ideological and Political Education System of College Students and Provide Organization Guarantee for Ideological and Political Education of College Students}

Strengthening integrated construction of ideological and political education of college students is the requirement to cultivate modern interdisciplinary talents, deal with diversification of social ideological trend as well as horizontal integration and common progress of all layers. In order to realize integration of ideological and political education system of college students, it is necessary to start with the following aspects: Firstly, exchange ideas, set up ideas of educating people by all people and the whole society. The core layer, second layer and the outermost layer must use their practical actions to build good campus environment and positive social atmosphere. Secondly, realize sharing of resources, motivate all resources good to ideological and political education of college students, establish platform of resource sharing between units of the same layer and layers, to support theory and practice, in-class and after-class activities of ideological and political education of college students and realize the maximum of resource utilization. Lastly, set up collaboration and innovation center of ideological and political education of college students and strengthen the research on integration mechanism. Take projects as the carrier, hold various parties of ideological and political education of college students, and let all layers participate in it, optimize ways of cooperation, promote investigation and realize resource sharing, information sharing, team building in the end to provide organization guarantee for ideological and political education of college students.

\section{Focus on Students and Innovate in Ways and Methods of Ideological and Political Education of College Students, Provide Unremitting Motive Force Supporting for Ideological and Political Education of College Students}

The student-oriented thought means taking students as the principal part and starting with requirements of students, driving progress and development of students through requirements and letting student-oriented concept run through the whole process of ideological and political education of college student. In order to achieve this purpose, the first is theoretical study. Change the "Duck-stuffing" type of teaching, use open questions to enlighten students to think independently, strengthen students' understanding for knowledge learnt by them, and arouse students' enthusiasm and initiative to participate in the class. The second is practice in class. Give students more autonomous rights and rights of choice in design and organization of practice. Teachers shall strengthen support, supervision, guidance and enlightenment in the practice process. The third is to actively set up new media network platform, use words, pictures, audios and videos that students love to see and hear, unconsciously put in contents of socialist ideology and improve effectiveness of ideological and political education of college student. The last is to meet requirements of university education and management reform, break the imprisonment of inherent thinking, let activities of ideological and political education of college student enter classroom, mass organization, laboratory, practice base and social activities of students. In addition, improve the quality of online courses related to ideological and political education of college student, gather a great deal of domestic famous specialists of ideological and political education, create numerous online courses with brands, realize sharing of high quality resources and strengthen appeal of these courses and get good effects of ideological and political education carried out by online courses.

To sum up, in face of opportunities and challenges brought by New Normal of ideological and political education of college students, organizer and implementer of ideological and political education of college students must keep clear understanding, intensify team construction, strengthen consciousness of responsibility, continuously improve and innovate in working method and enhance effects of ideological and political education of college students and make efforts to cultivate qualified builders and successors of socialism.

\section{REFERENCES}

[1] Li Shaoqi. Research on Ideological Education of College Students in Response to the Impact of Western Social Thoughts under Horizon of Cultural Security [J], Journal of Southwest University for Nationalities (Humanities and Social Science Edition), 2015(8).

[2] Liao Xiangzhong. What Is New Media? [J], Modern Communication 2008(5).

[3] Gao Aimin. Analysis on Necessity for Universities to Train Independent Consciousness of the 90s College Students [J], Journal of Hubei University of Economics (Philosophy and Social Science Edition), 2010 24(4).

[4] Zhou Fei, Li Yanchun. Socialist Core Values and Chinese Dream [J] Xinhua Digest, 2015(2). 